\title{
ANALISA PROJECT SISTEM INFORMASI PENJUALAN TAS "ELIZABETH" BERBASIS WEBSITE
}

\author{
Selvi Yulyanti ${ }^{1}$, Pirman Suryadi ${ }^{2}$, Ricky Firmansyah ${ }^{3}$ \\ Program Studi Sistem Informasi \\ Fakultas Teknologi Informasi \\ Universitas Adhirajasa Reswara Sanjaya \\ $\underline{\text { selviyulyanti123@gmail.com }}{ }^{1}$ pirmansoerjadi@gmail.com ${ }^{2}, \underline{\text { ricky@ ars.ac.id }}$
}

\begin{abstract}
ABSTRAK
Perkembangan teknologi dibidang usaha semakin meningkat. Kemajuan teknologi yang pesat dan meningkatnya kebutuhan informasi yang cepat dan tepat, komputer telah membantu untuk menghubungkan satu dengan yang lainnya. Langkah pertama dalam pembuatan bisnis untuk bersaing dengan para pesaingnya ialah dengan menggunakan komputer sebagai sarana untuk meningkatkan efektifitas kerja dan untuk meminimalisir kehilangan data. Perusahaan yang dulu masih manual dalam usahanya sekarang telah berganti dengan memanfaatkan kemajuan teknologi menggunakan sistem online. Salah satunya ialah penjualan tas "Elizabeth" yang dilakukan secara online. Selain itu keinginan untuk dapat berkembang dan meningkatnya penjualan yang tidak hanya dilakukan dengan datang ke toko, untuk mengatasi permasalahan tersebut maka penulis bermaksud untuk menganalisa sistem informasi penjualan berbasis website atau yang sering dikenal dengan E-Commerce.
\end{abstract}

Kata kunci: Penjualan, Sistem Informasi, Website

Abstract: The development of technology in the business sector is increasing. Rapid technological advances and the increasing need for fast and precise information, computers have helped to connect one another. The first step in getting a business to compete with its competitors is to use computers as a means to increase work effectiveness and to minimize data loss. Companies that used to be manual in their business have now replaced by taking advantage of technological advances using online systems. One of them is the online sale of the "Elizabeth" bag. In addition, the desire to be able to develop and increase sales is not only done by coming to the store, to overcome this problem, the author intends to analyze a website-based sales information system or what is often known as E-Commerce.

Keywords: E-commerce, Informatio System, Website

\section{PENDAhUluaN}

Seiring berkembang nya jaman dan pesatnya perkembangan teknologi banyak kegiatan yang dapat dilakukan dirumah salah satu contohnya adalah berbelanja, dijaman sekarang untuk berbelanja atau sering disebut online shoping sangat lah mudah dan efesien karena kini belanja bisa di lakukan dimana saja dan kapanpun dengan cara belanja online, selain dapat menghemat waktu kita juga tidak perlu datang langsung ke tokonya, disitu kita bisa melihat banyak barang yang ingin kita cari bahkan kita juga dapat melihat review dari para pelanggannya mengenai barang yang akan kita beli, sehingga belanja pun tidak perlu ragu.

Berbelanja melalui internet atau online shopping juga sering disebut dengan e-commerce. .
Menurut Husda (2012 : 167), e-commerce adalah kegiatan bisnis yang menyangkut konsumen (costumer), manufaktur (manufactures), service providers dan pedagang perantara (intermediaries) dengan menggunakan jaringan computer (computer networks) yaitu internet. Belanja online semakin populer dan menjamur dengan mulai banyak bermunculan toko-toko online seperti Bibli, Lazada, Tokopedia, Bhineka, Olx, Kaskus, Berniaga, PinkEmma dan lain-lain [1].

Pada saat ini banyak individu yang menggunakan website bukan hanya sekedar mencari informasi saja, melainkan sebagai lahan promosi, penjualan dan aktivitas lainnya yang dapat membuka peluang untuk bisnis. Selain itu website juga dapat mengoptimalkan pengunaan

JISICOM (Journal of Information System, Informatics and Computing)

http://journal.stmikjayakarta.ac.id/index.php/jisicom Telp.+62-21-3905050, e-mail:jisicom@stmikjayakarta.ac.id, jisicom2017@gmail.com 
komputer, sehingga dapat meminimalkan resiko kehilangan data [2].

Website toko online dapat memudahkan pelaku usaha atau toko untuk mempromosikan produk-produknya dan mempermudah konsumen untuk mendapatkan informasi tentang produkproduk yang dimiliki penjual atau toko. Keterbatasan Pemasaran produk menjadi suatu kendala toko dalam meningkatkan omset penjualan toko dan lemahnya pengawasan barang serta pembuatan laporan yang masih manual menjadi suatu dampak yang buruk bagi toko sehingga laporan penjualan dan laporan stok barang menjadi terhambat [3]. Kebutuhan untuk membangun website penjualan tidak hanya sekedar untuk mempromosikan barang, akan tetapi sebagai suatu usaha untuk mendapatkan pelanggan yang luas dimana tidak hanya konsumen yang berada disekitar toko fisik saja dapat membeli, namun peminat yang jauh berasal dari luar daerah sekalipun bisa mendapatkan informasi dan membeli produk yang dijual, juga untuk mengikuti trend pasar karena pasar berkembang sangat dinamis, memberikan pelayanan 24 jam dalam sehari karena dikerjakan oleh sistem, menghemat biaya untuk memperluas target pasar karena tidak memerlukan tenaga penjual dan bangunan toko yang banyak. Oleh karena itu, kebutuhan utama hasil sistem informasi pemasaran online merupakan sarana penting memperluas segmentasi pangsa pasar sehingga memiliki kesempatan yang lebih luas untuk meraih keuntungan dan daya saing secara lebih kompetitif [4].

\subsection{Identifikasi Masalah}

Dari beberapa masalah yang peneliti uraikan pada latar belakang maka dapat diidentifikasi sebagai berikut.

- Pelaku usaha rentan terhadap kehilangan data.

- Keterbatasan pemasaran produk menjadi suatu kendala dalam meningkatkan omset penjualan.

- Lemahnya pengawasan barang serta pembuatan laporan yang masih manual.

\subsection{Tujuan Penelitian}

Sesuai dengan identifikasi masalah yang dibuat dalam penelitian ini, peneliti memiliki beberapa tujuan yang ingin dicapai yaitu.
- Dengan adanya website penjualan online ini dapat mempromosikan barang dan melakukan penjualan secara online.

- Dengan adanya website ini dapat memudahkan konsumen dalam memesan, membeli ataupun membayar pesanan tanpa harus datang ke toko.

\section{METODE DAN MATERI}

\subsection{Metode Penelitian}

Metode penelitian yang kami gunakan adalah metode pengumpulan data dengan teknik Studi Kepustakaan.

Studi kepustakaan adalah metode mencari data atau informasi riset melalui jurnal ilmiah dan bahan-bahan publikasi lain yang tersedia di internet. Penulis mencari referensi serta pendukung penelitian berupa jurnal maupun contoh sistem yang serupa atau yang sudah ada untuk membantu menganalisa sistem informasi penjualan tas "Elizabeth".

\subsection{Sistem}

Menurut Jogiyanto H.M (2001) Sistem adalah suatu grup dari elemen-elemen baik berbentuk fisik maupun bukan fisik yang menunjukkan suatu kumpulan saling berhubungan diantaranya dan berinteraksi bersama-sama menuju satu atau lebih tujuan, sasaran atau akhir dari sistem [5].

\subsection{Informasi}

Menurut Jogiyanto H.M (2001 : 8) "Informasi adalah data yang diolah menjadi bentuk yang lebih berguna dan lebih berarti bagi yang menerimanya, informasi yang akurat akan memudahkan pihak manajerial untuk dapat melakukan analisa, evaluasi dan perencanaan" [6].

\subsection{Sistem Informasi}

Menurut O'Brien (2005), sistem informasi adalah suatu kombinasi teratur apapun dari people (orang), hardware (perangkat keras), Software (piranti lunak), computer networks and data communications (jaringan komunikasi), dan database (basis data) yang mengumpulkan, mengubah dan menyebarkan informasi di dalam suatu bentuk organisasi [7]. 


\subsection{Penjualan}

Penjualan ialah sebagai kegiatan manusia yang mengarahkan untuk memenuhi dan memuaskan kebutuhan dan keinginan melalui proses pertukaran [8].

\subsection{Website}

Menurut Mico Pardosi (2002: 10) "Website adalah kumpulan semua dokumen-dokumen didalam internet dan dokumen tersebut tersimpan dalam berbagai komputer yang disebut server" [6].

\section{PEMBahaSA DAN HASIL}
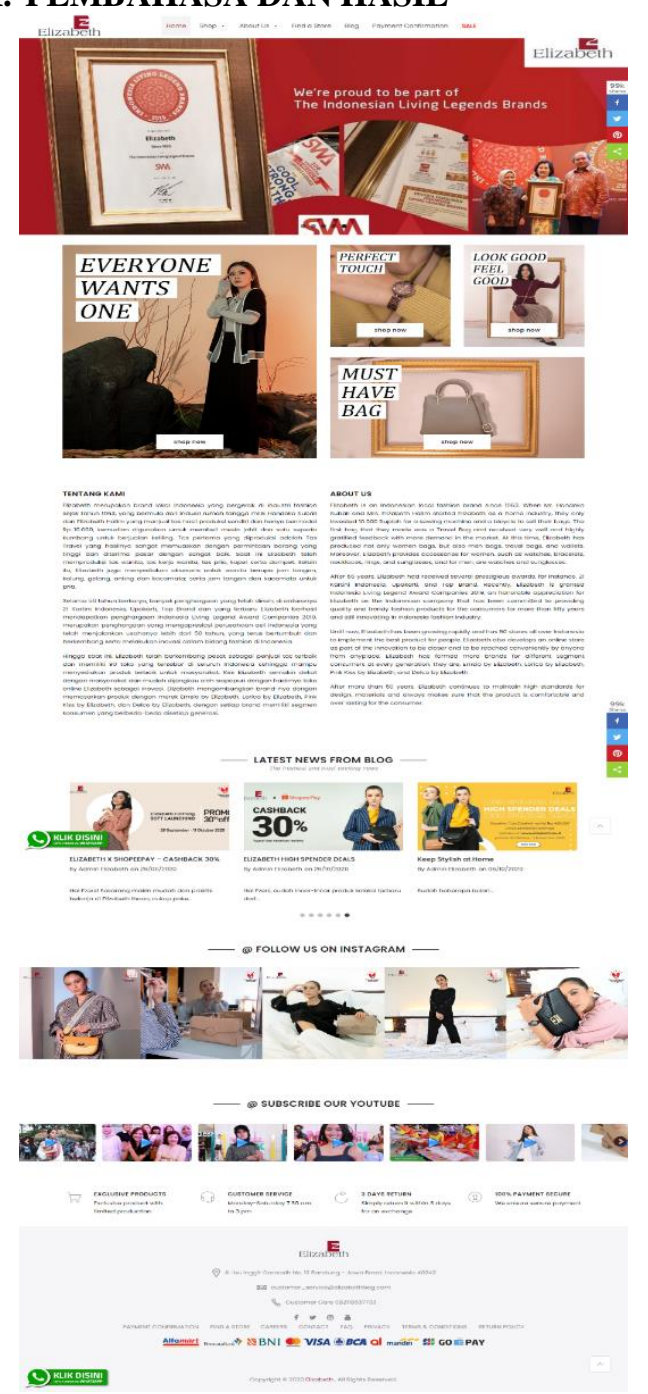

Gambar 1. Tampilan halaman homepage

\subsection{Tampilan Homepage}

Homepage merupakan halaman awal pada saat sistem ini di akses. Di dalamnya terdapat menu dibagian atas header diantaranya adalah home, shop, about us, find a store, blog dan payment confirmation. Terdapat banner iklan produk untuk menampilkan produk promo atau campaign. Dibawah banner iklan terdapat produk-produk rekomendasi. Pada bagian body terletak About Us yang berisi informasi blog. Dibawahnya terletak berita terbaru dari website tersebut. Lalu terdapat informasi sosial media dari website tersebut. Dan dibawahnya ada menu footer yang berisi informasi tentang website.

\subsection{Login User}

Halaman Login User merupakan halaman login untuk pelanggan dimana untuk melakukan transaksi pembelian pelanggan harus login terlebih dahulu ke sistem dengan cara menginputkan alamat email dan password. Apabila pelanggan salah menginputkan maka akan ada peringatan dari sistem. Apabila pelanggan belum mempunyai akun maka pelanggan dapat membuat akun pada halaman ini juga.

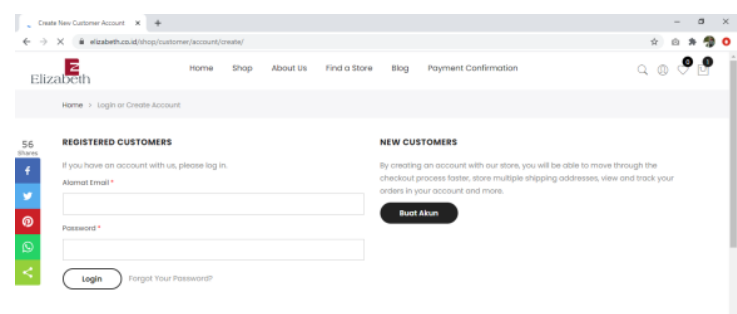

Gambar 2. Tampilan halaman Login User

\subsection{Halaman Produk}

Halaman ini akan tampil setelah kita memilih menu Shop. Halaman produk ini berisikan produk-produk yang tersedia di website beserta informasi harga dan icon untuk menandai produk yang disukai. Kita juga dapat menambahkan ke keranjang belanja jika ingin membeli produk tersebut dengan menekan tombol Add to Cart.

JISICOM (Journal of Information System, Informatics and Computing)

http://journal.stmikjayakarta.ac.id/index.php/jisicom Telp.+62-21-3905050, e-mail:jisicom@stmikjayakarta.ac.id, jisicom2017@gmail.com 


\section{Journal of Information System, Informatics and Computing}

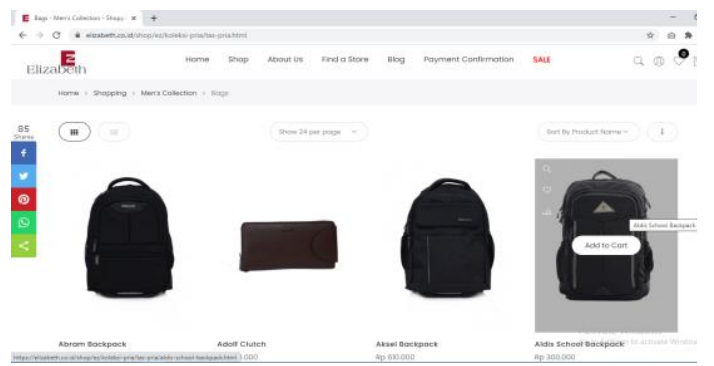

Gambar 3. Tampilan halaman produk

\subsection{Halaman Detail Produk}

Halaman ini akan tampil setelah kita menekan tombol Add to Cart. Halaman ini berisi informasi produk, kolom pilihan warna, kolom jumlah produk yang di ingin dimasukkan ke keranjang.

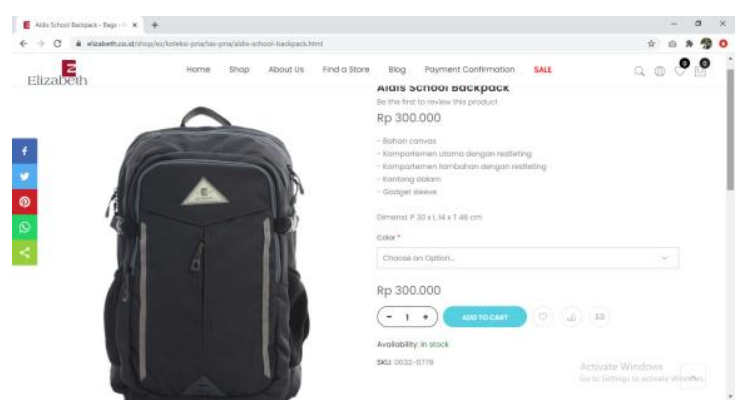

Gambar 4. Tampilan halaman detail produk

\subsection{Halaman Shopping Chart}

Halaman keranjang belanja merupakan halaman yang memuat daftar belanjaan yang akan di beli. Barang yang ingin dibeli akan ditampung disini dan pelanggan bisa menambah dan mengurangi daftar barang yang akan dibeli melaui halaman ini.

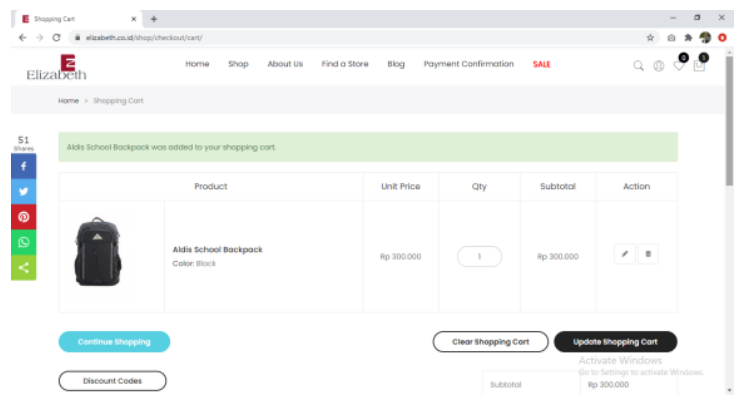

Gambar 5. Tampilan Shopping Cart

3.6. Halaman Checkout atau pemesanan

Halaman ini akan tampil ketika kita menekan logo keranjang lalu menekan tombol Checkout. Halaman ini berisi langkah-langkah untuk melakukan pemesanan.

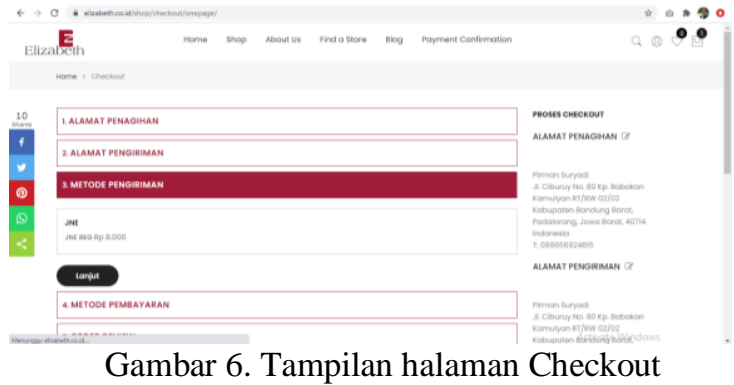

Setelah melakukan proses pemesanan, akan tampil pop up rincian pemesanan.

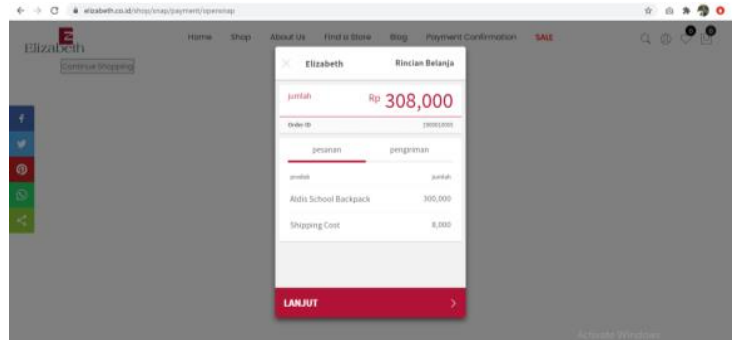

Gambar 7. Tampilan rincian belanja

mempercepat dalam transaksi penjualan sehingga sangat efisien.

4.2. Sistem yang dihasilkan membantu dalam mempromosikan produk-produk yang di jual oleh Elizabeth.
4.1. Sistem yang dibuat sudah berhasil diterapkan dan dijalankan dan mampu mempermudah maupun 


\section{Journal of Information System, Informatics and Computing}

4.3. Dengan adanya sistem ini, pengolahan data maupun pengambilan informasi dapat dilakukan dengan cepat, akurat, dan mudah.

4.4. Website ini memudahkan konsumen memesan dan membeli barang tanpa perlu datang ke toko langsung.

4.5. Namun sistem penjualan ini masih mempunyai beberapa kekurangan diantaranya masih melakukan pembayaran secara manual dan tidak terdapat multi bahasa

\section{REFERENSI}

[1] J. Setiawan, "RANCANGAN SISTEM INFORMASI PENJUALAN TAS BERBASIS WEB PADA 'GIKITA' ONLINE SHOP,' JURSIMA, vol. 6, 2018.

[2] N. Azwanti, "Sistem Informasi Penjualan Tas Berbasis Web Dengan Pemodelan UML," J. Ilmu Komput., vol. 4, 2017.

[3] A. P. Utomo and N. Mariana, "Analisis Tata Kelola Teknologi Informasi ( It Governance ) pada Bidang Akademik dengan Cobit Frame Work Studi Kasus pada Universitas Stikubank Semarang," J. Teknol. Inf. Din., vol. 16, no. 2, pp.
139-149, 2011.

[4] W. Onesimus, Modestus; Agasia, "Aplikasi Penjualan Berbasis Web Untuk Toko Tas Lutuna Pontianak," J. Online Mhs. Progr. Stud. Tek. Inform., vol. 2, 2019.

[5] N. Novita, Rice; Sari, "SISTEM INFORMASI PENJUALAN PUPUK BERBASIS ECOMMERCE," J. Teknoif, vol. 3, pp. 1-6, 2015.

[6] S. Louis, Ahmad; Kirana, "RANCANGAN SISTEM INFORMASI PENJUALAN BERBASIS WEBSITE PADA TINA MITRA," $J$. Akad., vol. 7, 2014.

[7] H. R. Maulana, Shabur Miftah; Susilo, "IMPLEMENTASI E-COMMERCE SEBAGAI MEDIA PENJUALAN ONLINE (STUDI KASUS PADA TOKO PASTBRIK KOTA MALANG)," J. Adm. Bisnis, vol. 29, 2015.

[8] L. Syahrizal, "SISTEM INFORMASI DAN PENJUALAN BERBASIS WEBSITE DI RINDU BATHI YOGYAKARTA," University of Technology Yogyakarta, 2019. 